\title{
Familial osteochondritis dissecans
}

INSERM

\section{Source}

INSERM. (1999). Orphanet: an online rare disease and orphan drug data base. Familial osteochondritis dissecans. ORPHA:251262

Familial osteochondritis dissecans is a rare genetic skeletal disorder characterized clinically by abnormal chondro-skeletal development, disproportionate short stature and skeletal deformation mainly affecting the knees, hips, ankles and elbows with onset generally in late childhood or adolescence. 